\title{
KONgEp tata RUANG RUMAH tinggal masYaRAKat KUTA DEsa kaRANGPANINGal kECAMATAN TAMBAKSARI KABUPATEN GIAMIS
}

\author{
SPATIAL CONCEPT IN THE HOUSE OF KUTA PEOPLE \\ IN DESA KARANGPANINGAL, KECAMATAN TAMBAKSARI, KABUPATEN \\ CIAMIS
}

\author{
Oleh Ria Intani T. \\ Balai Pelestarian Nilai Budaya Bandung \\ Jl. Cinambo No. 136 Ujungberung-Bandung \\ Email: kemuning13@gmail.com
}

\begin{abstract}
Abstrak
Penelitian konsep tata ruang rumah tinggal ini membahas mengenai bentuk rumah, penggunaan bahan bangunan dan cara membangun, aturan dalam tata letak rumah dikaitkan dengan keberadaan rumah lainnya, tata letak rumah dalam suatu areal, arah hadap rumah, pembagian ruang, dan aturan-aturan lain yang terkait yang menyertainya. Penelitian dilakukan untuk mendapatkan gambaran mengenai konsep tata ruang rumah tinggal di Kampung Kuta. Penelitian ini bersifat deskriptif dengan metode kualitatif, dengan tahapan kerjanya meliputi: studi pustaka, observasi, dan wawancara. Hasil penelitian menunjukkan bahwa sampai saat ini konsep tata ruang rumah di Kampung Kuta tetap berpegang teguh pada aturan yang diwariskan oleh para leluhur. Konsepnya adalah: Arah hadap rumah dilihat dari panjang rumah; Antara satu rumah dengan rumah yang lain harus berhadap-hadapan, tidak boleh saling memunggungi; Ruang-ruang yang terdapat dalam suatu rumah harus berhadapan dengan ruang yang sama pada rumah yang ada di depannya, dan sebagainya. Tabu atau pamali berperan dalam pelestarian adatistiadat yang berkenaan dengan konsep tata ruang rumah di Kampung Kuta.
\end{abstract}

Kata kunci: tata ruang, rumah, Kampung Kuta.

\begin{abstract}
This research discusses spatial concept in building a house and the relation among houses in the village of Karangpaningal. The aim of the research is to get an understanding of how the Kuta people build their houses according to their knowledge of spatial concept. The author conducted descriptive research using qualitative method. Data were collected through bibliographic study, observation, and interviews. The result shows that the people of Kuta are still clinging to the concept that was inherited from
\end{abstract}


their ancestors, for example the houses must be facing towards each other. Even a room in one's house must be in the same line with the room inside the house in front of his. It is taboos or pamali that have major role in preserving this customs.

Keywords: spatial concept, house, Kuta villa

\section{A. PENDAHULUAN}

Kebutuhan setiap manusia secara garis besar terbagi atas kebutuhan primer dan kebutuhan sekunder. Kebutuhan primer manusia adalah berupa sandang, pangan, dan papan. Ketiga faktor tersebut merupakan satu kesatuan yang tidak dapat dipisahkan. Berbicara tentang papan adalah berbicara tentang rumah (baca: rumah tinggal). Apabila rumah dikaitkan dengan masalah ruang dan waktu maka ada sebutan rumah modern dan rumah tradisional. Rumah modern keberadaannya mendominasi wilayah perkotaan. Sebaliknya, rumah tradisional keberadaannya mendominasi wilayah pedesaan.

Istilah tradisional mengandung arti sebagai mentradisi, yaitu mentradisi dalam penggunaan bahan bangunan; mentradisi dalam cara membangun; dan mentradisi dalam pengetahuan tentang bahan bangunan, cara membangun, dan aturan-aturan lain yang terkait yang menyertainya.

Bangunan rumah tradisional dicirikan dengan penggunaan bahan bangunan dari lingkungan sekitar dan cara membangun mengikuti aturan-aturan yang diwariskan dari pendahulunya. Selain itu, dicirikan pula pada adanya keselarasan dengan alam, dengan kehidupan sosial, dan dengan Sang Pencipta. Rumah tradisional seperti itu banyak dijumpai di lingkungan komunitas adat.

Berbicara tentang komunitas adat selalu terkait dengan kekentalan tradisi untuk melangsungkan tatanan kehidupan. Konsep dan kriteria tentang komunitas adat menurut Ade M. K. (2011:2) adalah:

- Suatu kesatuan sosial yang dalam melangsungkan interaksi sosialnya melibatkan hubungan yang intensif dengan frekuensi yang sangat tinggi sehingga hubungan sosialnya bersifat bertatap muka (face-to-face), kuat dan kokoh menjalankan tradisi yang wujud sejak awalnya.

- Hubungan sosial berdasarkan :

(1) ikatan kekeluargaan; (2) ikatan persahabatan yang erat; (3) mengarah pada perasaan "kekitaan" bagi segenap warganya; dan (4) motivasinya bercorak affective.

- Penyeragaman kesatuan tempat tinggal, fisik rumah dan aturan.

Komunitas adat seperti dicirikan di atas, beberapa terdapat di Provinsi Jawa Barat; di Kabupaten Bandung ada komunitas adat Mahmud, di Kabupaten Garut ada komunitas adat Pulo dan Dukuh, di Kabupaten Tasikmalaya ada komunitas adat Naga, dan di Kabupaten Ciamis ada komunitas adat Kuta.

Komunitas adat Kuta terdapat di Kampung Kuta. Mereka ada di bawah pimpinan seorang ketua adat dan seorang kuncen. Keduanya berperan sebagai pemangku adat yang mengendalikan keberlangsungan tradisi. Kekentalan tradisi yang tampak di antaranya mewujud dalam kesamaan bahan bangunan, bentuk rumah dan pembagian ruangnya, cara membangun, dan tata letak rumah.

Adanya tradisi seperti di atas memunculkan pertanyaan: seperti apa konsep tata ruang rumah tinggal di Kampung Kuta? Oleh karenanya tujuan dari penelitian ini untuk mengetahui konsep tata ruang rumah tinggal yang ada di Kampung Kuta. Penelitian dibatasi di wilayah Kuta Jero. Adapun materinya dibatasi pada: bentuk rumah, penggunaan bahan bangunan dan cara membangun, 
aturan dalam tata letak rumah dikaitkan dengan keberadaan rumah lainnya, tata letak rumah dalam suatu areal, arah hadap rumah, pembagian ruang, dan aturan-aturan lain yang terkait yang menyertainya. Jenis penelitian ini deskriptif dengan metode kualitatif. Teknik penelitiannya dilakukan dengan studi pustaka, observasi, dan wawancara.

\section{B. HASIL DAN BAHASAN}

Kampung Kuta berada di Desa Karangpaningal, Kecamatan Tambaksari, Kabupaten Ciamis. Di sebelah utara, Kampung Kuta berbatasan dengan Dusun Cibodas; di sebelah barat dengan Dusun Margamulya; dan di sebelah timur dengan Sungai Cijolang, pembatas Provinsi Jawa Barat dengan Jawa Tengah.

Kampung Kuta berjarak sekitar 34 $\mathrm{km}$ dari ibu kota Kabupaten Ciamis. Keberadaannya di suatu lembah yang dikelilingi tebing hingga terpisah dengan kampung lainnya. Kampung Kuta sangat subur namun kondisi tanahnya labil. Kampung ini berada pada ketinggian 500 $\mathrm{m}$ di atas permukaan laut.

Luas wilayah Kuta 97 ha, mencakup 40 ha hutan lindung, permukiman, sawah, ladang, kebun, kolam ikan, jalan, tanah lapang, gunung dan mata air keramat. Kampung Kuta dapat dibedakan menjadi kawasan Kuta Jero dan Kuta Luar. Kuta Jero, wilayahnya di antara Sungai Cijolang sampai dengan gapura bertuliskan Kuta Jero. Adapun Kuta luar wilayahnya dari gapura Kuta Jero sampai batas gapura desa. Antara Kuta Jero dan Luar sama dalam hal adat- istiadatnya.

Rumah-rumah di Kampung Kuta berjajar di tepi jalan kampung atau mengelompok pada tanah yang datar. Kelompok rumah yang satu dengan lainnya berjauhan. Setiap rumah berpekarangan luas dengan tanaman pokoknya kawung.

Gbr. 1 Pola Permukiman

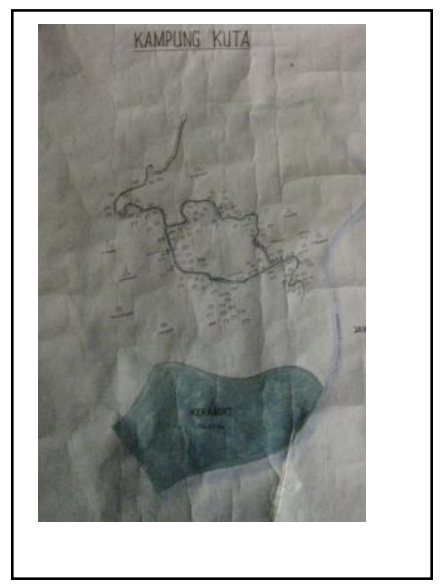

Dok: Penelitian 2012

Kampung Kuta berpenduduk 325 jiwa. Penduduk laki-laki sebanyak 159 jiwa dan perempuan sebanyak 166 jiwa. Mayoritas mata pencaharian penduduknya sebagai perajin gula aren. Lainnya sebagai perajin anyaman, kuli bangunan, mandor, petani, dan peternak. Pada umumnya penduduk berpendidikan tamat sekolah dasar (SD) dan seluruhnya beragama Islam.

Ada beberapa upacara tradisional yang dilakukan masyarakat Kuta, yaitu: upacara mendirikan dan mendiami rumah baru, Nyuguh, Hajat Bumi, dan Babarit. Masyarakat Kuta juga percaya terhadap tabet-tabet 'tempat-tempat yang dikeramatkan', seperti leuweung karamat, Gunung Wayang, Gunung Panday Domas, Gunung Barang, Gunung Batu Goong, dan Ciasihan; Selain itu, juga percaya pada adanya hari, nama, arah, dan tempat yang baik. Beberapa kegiatan yang didasarkan pada perhitungan antara lain: memberi nama pada bayi, melakukan pekerjaan, mendirikan rumah, pindah rumah, dan menentukan arah berikut tata letak rumah yang akan dibangun, serta menentukan hari perkawinan dan khitanan.

Ada dua versi tentang asal-usul Kampung Kuta. Versi pertama adalah masa Kerajaan Galuh dan versi kedua adalah masa Kerajaan Cirebon. Versi sahkan bahwa Kampung 
Kuta dahulu merupakan tempat yang batal menjadi ibu kota Kerajaan Galuh. Selanjutnya masyarakatnya mengaku sebagai keturunan Raja Galuh dan keberadaannya di Kuta untuk menjaga kekayaan Raja Galuh. Penamaan Kuta sesuai letaknya yang berada di sebuah lembah dan dikelilingi tebing. Dalam bahasa Sunda, daerah demikian disebut kuta.

Versi kedua mengisahkan bahwa Kerajaan Cirebon dan Kerajaan Mataram menaruh perhatian atas peninggalan Raja Galuh. Adanya perhatian tersebut disebabkan para penguasanya mendapat amanat dari leluhurnya untuk memelihara daerah tersebut. Utusan Kerajaan Cirebon, Raksabumi, rupanya lebih awal tiba di Kuta. Demikian akhirnya Raksabumi menjaga Kampung Kuta hingga akhir hayatnya. Setelah meninggal, Raksabumi dimakamkan di Cibodas dan dikenal dengan nama $\mathrm{Ki}$ Bumi. Dia dianggap sebagai cikal bakal masyarakat Kuta. Sampai sekarang Kampung Kuta dipimpin oleh keturunan Ki Bumi.

Dewasa ini di Kampung Kuta terdapat 126 rumah tinggal. Secara fisik, keseluruhan rumah memiliki kesamaan. Rumah-rumah berbentuk panggung, tidak boleh nyekon (menyiku) seperti leter L. Atap rumah menyerupai bangun trapesium dengan ditutup rumbia atau ijuk. Dinding rumah terbuat dari bilik atau triplek. Tiang-tiang penyangga dari kayu, jendela dari gebyok (papan) atau dari kaca. Tiang-tiang utama rumah berdiri pada tatapakan (batu pahat) dengan demikian rumah memiliki kolong. Di bagian pintu depan dibuat tangga yang disebut golodog yang juga berfungsi untuk duduk-duduk.
Gbr. 2 Rumah Panggung

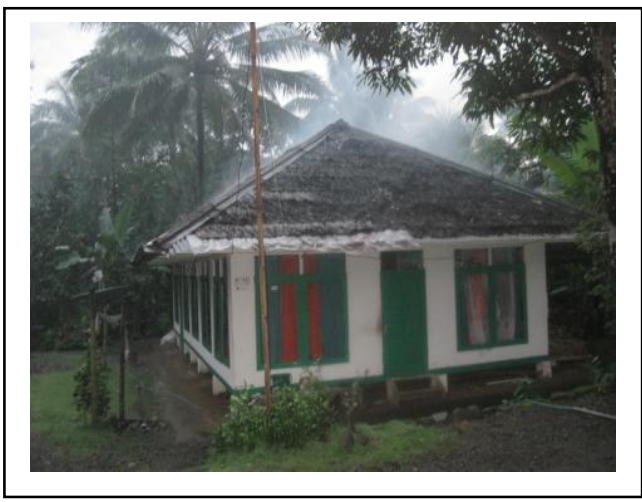

Dok: Perekaman 2011

Bangunan rumah tidak boleh bertembok dan bergenteng. Larangan ini dimaksudkan agar penghuni rumah tidak seperti dikubur. Apabila bahan bangunan rumah dari tanah (genteng) serta letaknya melebihi batas kepala manusia, sama artinya dengan dikubur. Istilah kuncen adalah tidak boleh membuat istana (baca: rumah) jadi astana (kuburan). Apabila larangan tersebut dikaitkan dengan kondisi tanah yang labil, maka pemberlakuan larangan tersebut sesungguhnya merupakan upaya adaptasi terhadap kondisi geografis Kuta. Logikanya, rumah bertembok dan bergenteng akan menambah bobot tekanan terhadap tanah. Rumah bisa mendesak ke tanah dan kemudian ambruk.

Bagian-bagian dari bangunan rumah tinggal terdiri atas:

- Atap

Atap rumah berbentuk limasan dengan penutupnya kiray atau ijuk 
Gbr. 3 Atap

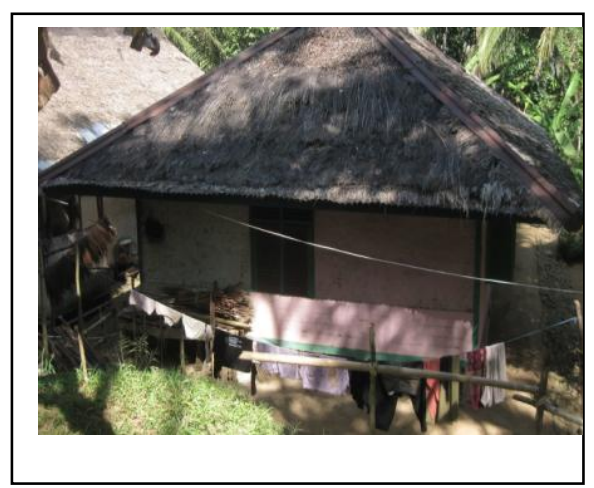

\section{- Plafon/Langit-langit}

Plafon terbuat dari bilik (anyaman bambu) dengan motif kepang. Tidak seluruh ruangan rumah menggunakan plafon. Ruangan rumah yang tidak menggunakan plafon adalah pawon (dapur).

\section{Gbr. 4 Plafon}

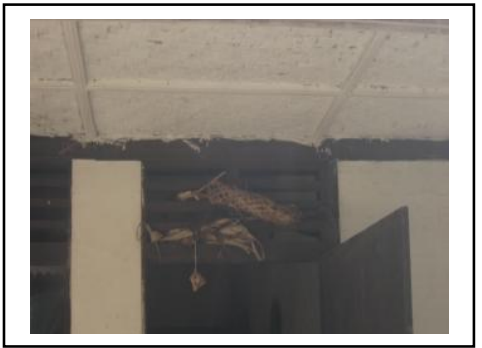

Gbr. 5 Pawon Tidak Berplafon

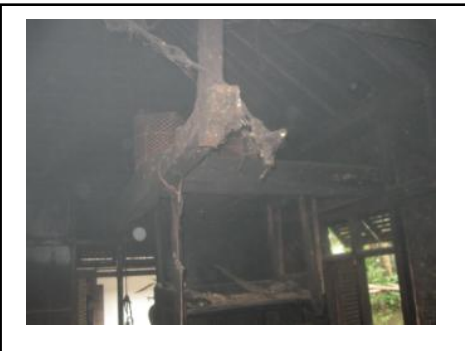

\section{- Tiang}

Tiang rumah dari kayu dan fondasinya dari batu alam.
Gbr. 6 Tatapakan

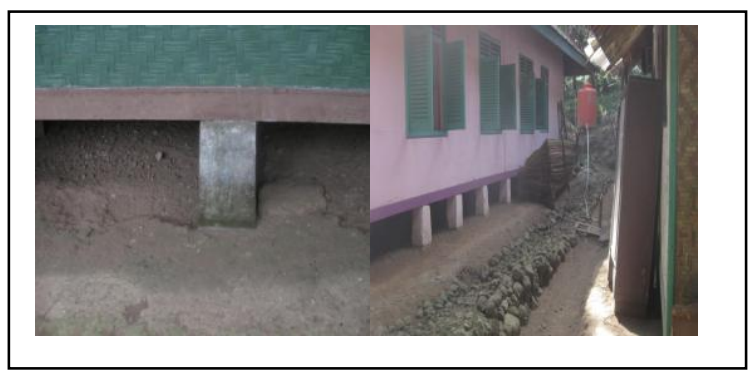

Dok: Penelitian

\section{- Dinding}

Dinding rumah terbuat dari bilik atau triplek.

Gbr. 7 Dinding Bilik

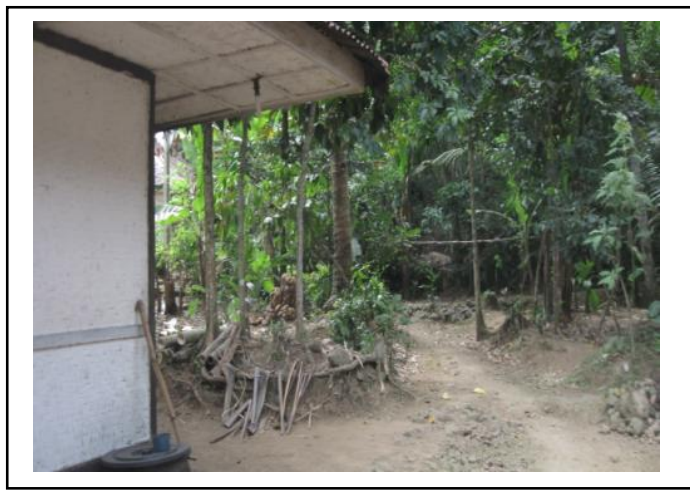

Dok: Penelitian 2012

\section{- Pintu}

Rumah tinggal memiliki satu pintu depan menuju ke los, pintu menuju tengah imah (ruang tengah), pintu penghubung antara los dan tengah imah, dan pintu belakang di bagian dapur. Selain itu, ada beberapa pintu lain yaitu pintu kamar tidur dan pintu goah (ruang tempat menyimpan padi). Pintu umumnya berbentuk persegi panjang dan terbuat dari papan. Ada pula dapur rumah yang berpintu sorong (geser) dari bambu. Jumlah pintu disesuaikan kebutuhan. 


\section{- Jendela}

Jendela terletak di bagian depan, di samping, dan di bagian belakang bangunan rumah. Jendela dengan daun atau tanpa daun jendela. Jendela terbuat dari kayu atau kaca sebagai penutupnya. Jumlah jendela disesuaikan kebutuhan. pawon terletak sejajar, sedangkan enggon berada di tepas. Demikian pula kalau ada los, maka los, tengah imah, dan pawon terletak sejajar, dan enggon berada di tengah imah.

Gbr. 8 Jendela

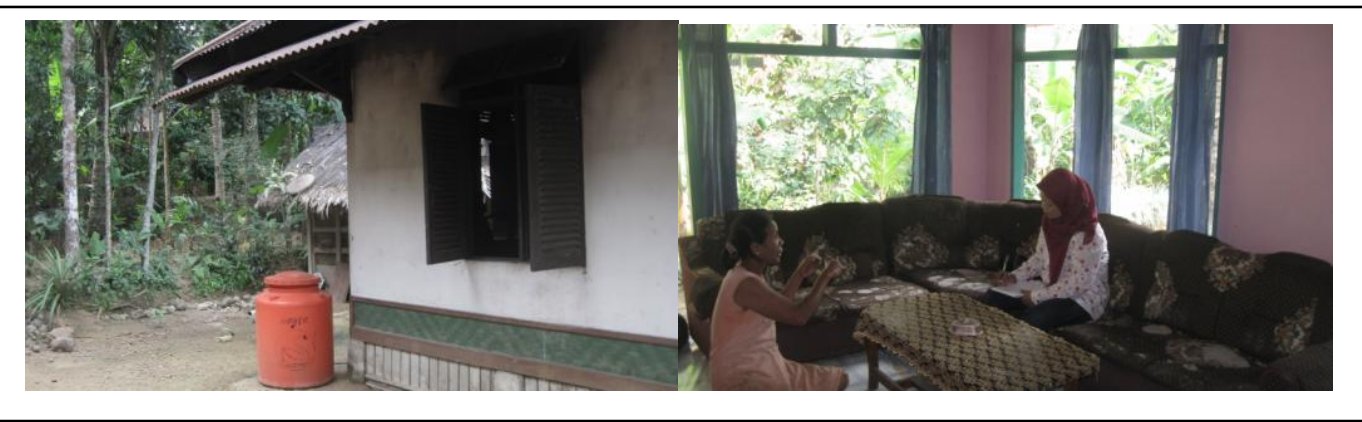

\section{- Lantai}

Lantai rumah dari papan atau palupuh, dan tanah untuk sekitar pawon.

\section{Gbr. 9 Los Berlantai Palupuh}

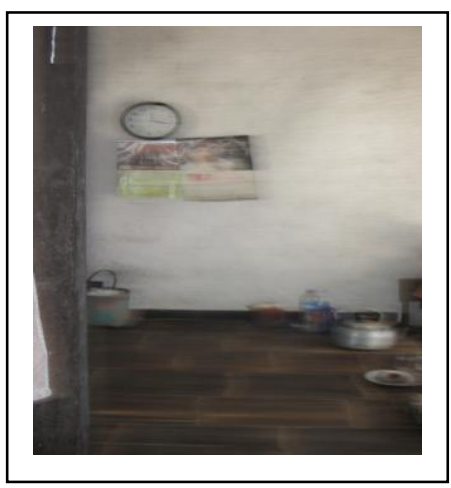

Dok: Penelitian 2012

Dulu, rumah-rumah di Kampung Kuta hanya memiliki tiga ruangan yaitu enggon (kamar tidur), tepas, dan pawon. Bangunan rumah seperti ini kini hampir tidak ada lagi. Kini rumah-rumah pada umumnya memiliki empat ruangan yaitu enggon, tengah imah, los, dan pawon.

Bentuk rumah tinggal di Kampung Kuta persegi panjang sehingga tepas dan
Ruang dan fungsi masing-masing ruang rumah sebagai berikut:

- Tepas

Tepas merupakan ruangan yang terletak di bagian kanan atau kiri bangunan rumah tinggal (dilihat dari depan rumah). Tepas memiliki fungsi ganda dan bahkan dalam keadaan terpaksa memiliki tiga fungsi sekaligus yaitu: sebagai ruang tamu, ruang keluarga, dan bisa dijadikan ruang untuk tidur tamu.

\section{- Tengah Imah (Tengah Rumah = Ruang Keluarga)}

Tengah imah merupakan ruangan yang terletak di paling kanan atau kiri bangunan rumah tinggal (dilihat dari depan). Tengah imah berfungsi sebagai ruangan untuk berkumpul keluarga. Di tengah imah terdapat enggon untuk tidur orang tua dan anak. Isi tengah imah maupun tepas menunjukkan adanya kesamaan. Apabila tidak ada los, maka tidak ada ruangan yang disebut dengan tengah imah. Apabila ada los, tepas 
berubah fungsi menjadi tengah imah karena ruangan untuk menerima tamu sudah digantikan oleh los.

Gbr. 10 Tengah Imah

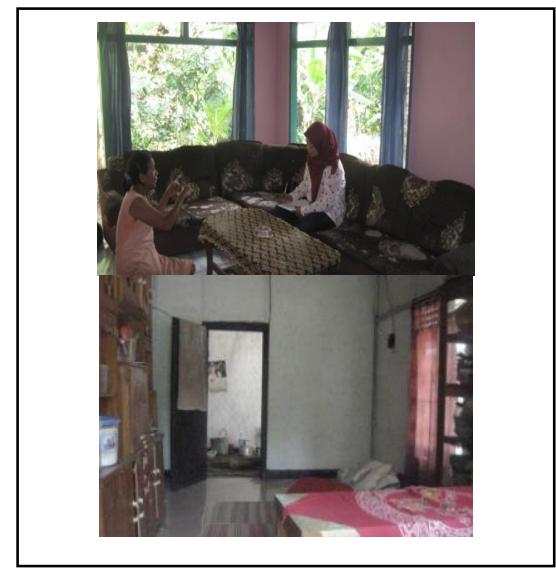

Dok: Penelitian 2012

\section{- Enggon (Kamar Tidur)}

Enggon berada di tepas atau tengah imah dengan pintu menghadap ke tepas atau tengah imah. Jumlah enggon disesuaikan dengan kebutuhan, biasanya dikaitkan dengan jumlah anak. Jumlah enggon pada umumnya dua.

\section{Gbr. 11 Enggon}

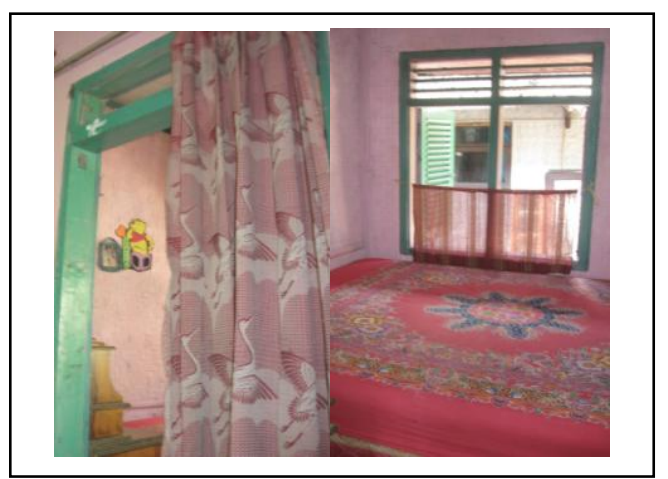

Dok: Penelitian 2012
- Los

Los sebenarnya diartikan sebagai gang, apalagi kalau melihat letaknya ada di antara tengah imah dan pawon. Namun demikian los ini tidak berfungsi sebagai gang dalam arti sebenarnya, melainkan merupakan sebuah ruangan. Los berlantaikan papan atau bambu. Tinggi lantai los sama dengan lantai tengah imah. Los berfungsi untuk menerima tamu. Oleh karena fungsinya itu, maka tamu yang datang akan masuk dari pintu los. Pintu los menjadi pintu utama suatu bangunan rumah sekaligus dapat menunjukkan arah hadap rumah.

Gbr. 12 Los

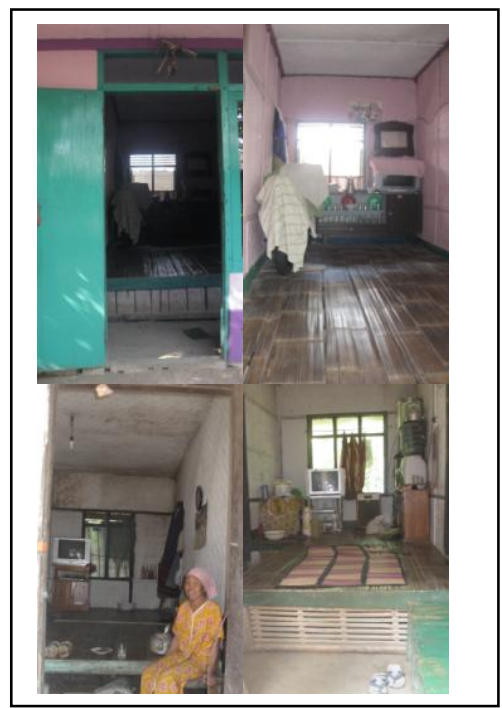

Dok: Penelitian 2012

\section{- Pawon (Dapur)}

Pawon identik dengan tempat kotor, tidak heran kalau lantainya ngupuk (langsung tanah). Terdapat parako yaitu tempat hawu (perapian) dan paraseuneu (sebuah tempat dari bambu yang letaknya di atas hawu, menggantung pada atap, untuk menyimpan segala kebutuhan dapur). Pawon bisa berada di bagian bangunan rumah paling kanan atau kiri, bergantung kemana rumah itu menghadap. Pintu pawon menyambung ke tepas atau los. Di pawon, biasanya 
terdapat pula goah tempat menyimpan padi atau beras.

\section{- Jamban (Kamar Mandi)}

Jamban terletak terpisah dari bangunan rumah. Ada di sebelah selatan atau barat rumah, atau ada di tepi balong (kolam ikan) atau pancuran.

\section{Gbr. 13 Jamban}

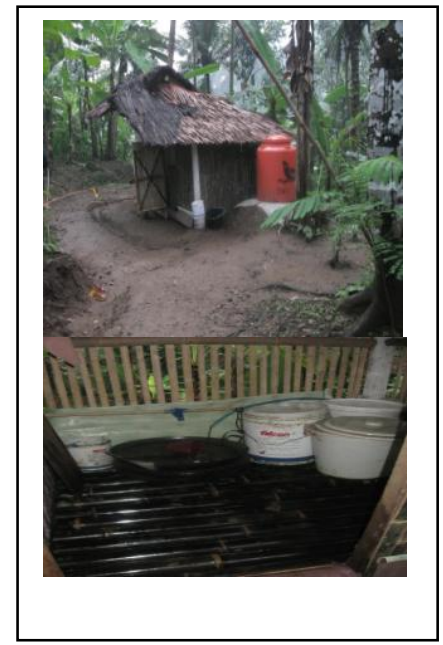

Dok: Penelitian

Dalam membangun rumah, selain harus memerhatikan material yang digunakan dan bentuk rumah itu sendiri, juga harus mengikuti konsep tata ruang yang sudah menjadi aturan adat di Kampung Kuta.

Bagi setiap warga yang akan mendirikan rumah, ada beberapa hal yang harus menjadi perhatian. Pertama, kepala keluarga harus mengetahui hari kelahirannya. Hal ini disebabkan arah hadap rumah yang akan dibangun ditentukan berdasarkan hari kelahiran kepala keluarga. Berikut ketentuannya:

- Kelahiran hari Senin : menghadap timur utara

- Kelahiran hari Selasa : : menghadap timur utara

- Kelahiran hari Rabu : menghadap selatan barat
- Kelahiran hari Kamis : menghadap timur selatan

- Kelahiran hari Jumat $\quad$ : menghadap timur

- Kelahiran hari Sabtu $\quad$ : menghadap utara

- Kelahiran hari Minggu : menghadap selatan barat

Apabila kepala keluarga telah mengetahui arah hadap rumah yang akan dibangun, selanjutnya ia harus memerhatikan apakah di sebelah tanah miliknya yang akan dibangun sudah terlebih dahulu berdiri rumah yang lain atau belum. Apabila belum berdiri rumah yang lain, maka ia tinggal membangun rumah dengan arah hadapnya disesuaikan dengan hari kelahirannya. Sedangkan apabila telah berdiri rumah yang lain, maka rumahnya harus menyesuaikan dengan rumah yang sudah terlebih dulu berdiri.

Arah hadap rumah dilihat dari panjang rumah, bukan lebarnya. Antara rumah yang satu dengan rumah yang lain tidak boleh ngagendong (baca: memunggungi), melainkan harus saling berhadapan. Apabila rumah yang terlebih dulu berdiri memiliki empat ruang utama (enggon, tengah imah, los, dan pawon), maka rumah yang akan menyusul dibangun harus memiliki empat ruang utama pula. Masing-masing ruang di dalam satu rumah, posisinya berhadapan dengan ruang-ruang yang sama pada rumah yang ada di depannya. Menurut leluhur mereka, antarruang yang sama harus melayani. Pawon berhadapan dengan pawon, los berhadapan dengan los, tengah imah berhadapan dengan tengah imah, dan enggon ada di tengah imah. Apabila rumah yang terlebih dulu berdiri hanya memiliki tiga ruang utama seperti enggon, tepas, dan pawon, maka rumah yang akan berdiri di depannya harus memiliki tiga ruang pula. Masingmasing ruang posisinya harus berhadapan. Pawon berhadapan dengan 
pawon, tepas berhadapan dengan tepas, dan enggon ada di tepas.

\section{Gbr . 14 Rumah Harus \\ Saling Berhadapan}

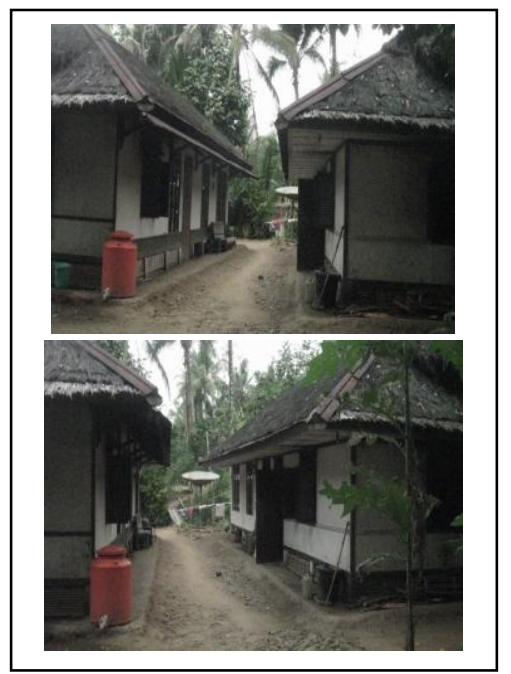

Dok: Penelitian 2012

Apabila rumah berjajar ke samping, maka posisi pawon harus melayani (berhadapan) dengan pawon (yang tua berhadapan dengan yang tua). Dengan demikian rumah yang ada di sebelah kanan (dilihat dari depan) terdiri atas: ruang paling kanan adalah tengah imah (ada enggon), ke arah kiri adalah los, dan paling kiri adalah pawon. Sedangkan rumah yang ada di sebelah kiri (dilihat dari depan) terdiri atas: ruang paling kanan adalah pawon, ke arah kiri adalah los, dan paling kiri adalah tengah imah.
Gbr. 15 Pintu Los Berhadapan dengan Pintu Los

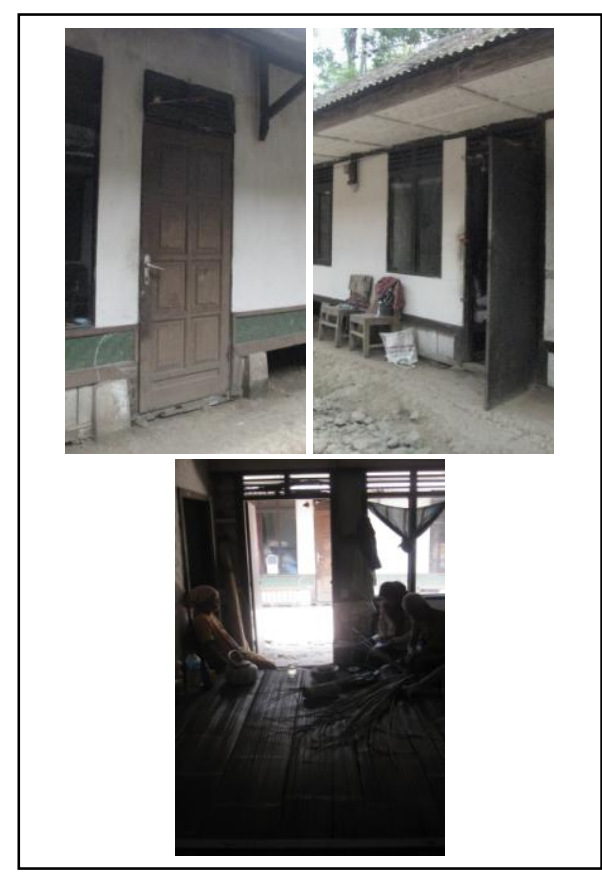

Dok: Penelitian 2012

Apabila ruman yang akan dibangun berdasarkan hari kelahiran posisinya "melawan" ketentuan adat, dalam arti tidak bisa berhadapan dengan rumah yang sudah berdiri sebelumnya, melainkan memunggungi alias ngagendong, maka kepala keluarga harus mencari tempat yang lain. Kepala keluarga harus mendapatkan tanah yang masih kosong atau belum berdiri rumah sehingga tidak perlu menyesuaikan dengan rumah lain. Atau, mencari tempat yang bisa dibangun sesuai konsep tata ruang yang berlaku. Konsep tata ruang yang berlaku yaitu arah hadap rumah sesuai dengan hari kelahiran kepala keluarga dan rumah yang berdekatan harus dalam posisi saling berhadapan, demikian pula dengan ruang per ruangnya. Konsep tata ruang seperti itu merupakan amanah leluhur yang mereka sendiri kurang dapat memahami apa maksudnya. Namun demikian apabila amanah tersebut dilanggar, konon bagi mereka yang melanggarnya akan terkena 
dampak. Bisa berupa masalah kesehatan, rizki, dan lain sebagainya yang mengenai penghuni rumah. Adanya dampak negatif yang terwacanakan di antara warga, membuat warga tidak berani melanggar amanah.

Sebenarnya, posisi ngagendong bukan tidak boleh sama sekali. Posisi ngagendong diperbolehkan selama jarak antara satu rumah dengan rumah yang lain cukup jauh, sekitar seratus meteran dan biasanya sudah dipisahkan dengan "pagar". Apakah pagar itu dari bambu, tanaman, atau semak belukar. Rumah yang berjarak seratus meteran tadi akan berhadapan dengan rumah lainnya.

\section{Gbr. 16 Kedua Rumah Tidak} Pagendong-gendong

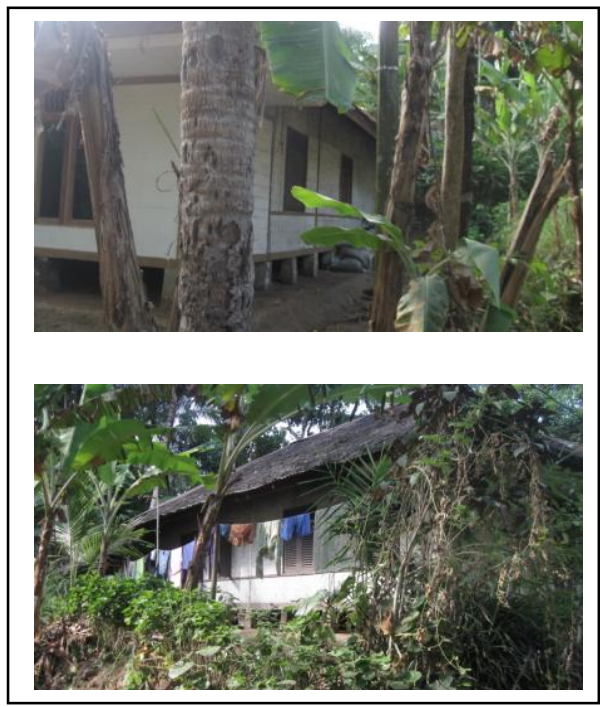

Dok: Penelitian 2012

Pada umumnya tiap-tiap warga Kuta memiliki tanah yang cukup luas. Pada saat mendirikan rumah, tidak ada ketentuan di sebelah mana rumah itu harus berdiri. Namun demikian pada umumnya mereka "membuat" jarak antara rumah dengan jalan. Kalau memungkinkan, jarak rumah dengan jalan sebaiknya berkisar dua meteran. Maksudnya untuk menjaga kesehatan, kegaduhan, dan lain sebagainya. Apabila terlalu dekat dengan jalan, rumah akan banyak debu dan agak bising karena jalan merupakan tempat lalu lalang orang maupun kendaraan.

Letak rumah tidak harus persis di tengah-tengah suatu areal. Sisa lahan alias pekarangan bebas ditanami segala jenis tanaman. Penanaman tanaman menyesuaikan lahan, pada umumnya di samping kiri dan kanan rumah.

Selanjutnya, pembuatan ruangruang di dalam rumah pun ada aturannya. Enggon harus sejajar dengan pawon. Tepatnya, enggon harus sejajar dengan goah atau hawu, dalam istilah mereka melayani. Antara enggon yang satu dengan enggon yang lain harus sejajar, istilah mereka jangan pasengsolan (tidak sejajar). Selain itu, letak enggon orang tua adalah yang paling dekat dengan pawon. Pawon oleh mereka dianggap tua, jadi antara yang tua dengan yang tua harus sejajar dan saling berdekatan. Selain itu, letak gudang padi harus sejajar dengan goah atau hawu, istilah mereka harus melayani.

Terkait dengan masalah ruang tentu saja tidak dapat dilepaskan dengan pintu. Pada tepas atau tengah imah terdapat pula pintu samping. Tidak jarang posisi pintu samping lurus sejajar dengan pintu penghubung dari tengah imah menuju los. Dengan demikian apabila kita berdiri di luar rumah, akan dapat langsung melihat los. Pintu lurus sejajar seperti ini diperbolehkan selama ada dinding yang menghalangi pawon. Maksudnya, di los terdapat penyekat yang memisahkan antara los dengan pawon sehingga dari luar rumah tidak langsung terlihat pawon. Sedangkan yang tidak boleh adalah apabila pintu samping lurus sejajar dengan pintu pawon sehingga dari luar rumah langsung terlihat pawon. Menurut istilah mereka, pintu samping tengah imah atau tepas tidak gorok atau labas (tanpa penghalang) dengan pawon. Apabila labas, dipercaya rizki yang diterima tidak akan menyangkut atau habis begitu saja. 
Gbr. 17

Pintu Samping Lurus Sejajar dengan Pintu Menuju Los

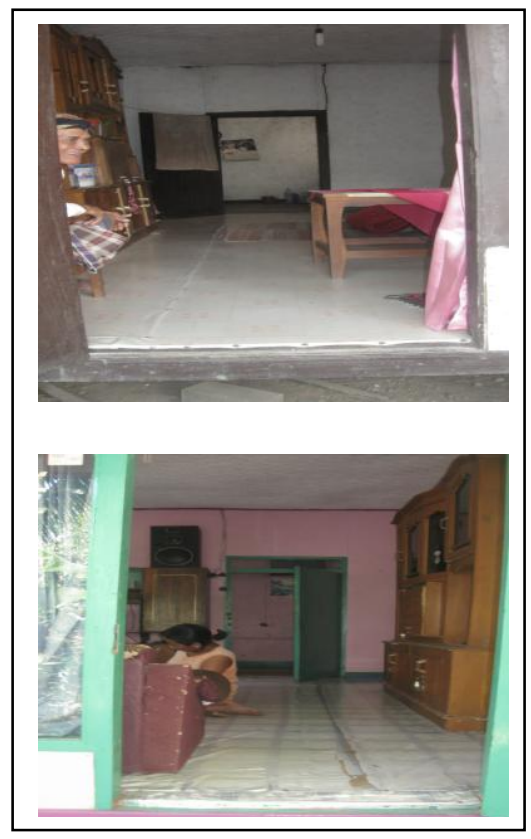

Dok: Penelitian 2012

Selain terkait dengan masalah ruang, masih ada aturan lainnya yaitu berkenaan dengan letak rumah orang tua, rumah anak, dan letak rumah anak yang lebih tua dengan yang lebih muda. Bukan merupakan keharusan rumah orang tua berdekatan dengan rumah anaknya. Namun demikian apabila rumah orang tua memang berdekatan dengan rumah anaknya, maka posisi rumah orang tua harus ada di sebelah timur rumah anaknya. Atau dengan kata lain, posisi rumah anak ada di sebelah barat rumah orang tuanya. Adapun apabila rumah antaranak (kakak beradik) saling berdekatan, maka rumah anak yang lebih tua usianya (kakaknya), apa pun jenis kelaminnya, harus ada di sebelah timur rumah anak yang lebih muda (adiknya). Apabila ketentuan tentang posisi rumah ini dilanggar, istilah mereka adalah ngalangkangan, maka penghuni rumah bisa terkena dampaknya berupa musibah.
Posisi rumah orang tua atau saudara yang lebih tua usianya harus ada di sebelah timur, oleh karena menurut leluhur arah timur merupakan wiwitan 'asal', jadi harus menyesuaikan asal.

Selanjutnya, apabila semua aturan di atas yaitu aturan tentang material rumah, tentang bentuk rumah, tentang konsep tata ruang rumah, dan tentang letak rumah semua sudah dipahami, ada satu hal lagi yang harus dijadikan bahan pertimbangan apabila akan membangun rumah. Hal tersebut tidak lain terkait dengan baik atau tidaknya suatu lahan dibangun rumah oleh suatu keluarga. Biasanya, setelah kepala keluarga sudah memungkinkan mendirikan rumah di suatu lahan, maka sebelum sampai pada tahap membangun, ia akan mencoba "mengetes" tanah yang akan dibangun rumah. Caranya dengan neyag yaitu membuat kuburan padi.

Neyag ada beberapa tahapan. Tahapan neyag yaitu: pertama membuat logak 'lubang'. Kedua, padi dililitkan ke satu ruas bambu yang sudah diisi air. Dan ketiga, padi diletakkan di dalam logak lalu ditutup dengan menggunakan haseupan 'kukusan'. Percobaan atau pengetesan tadi dilakukan pada hari kelahiran kepala keluarga akan tetapi dijatuhkan pada penanggalan kliwon. Dimisalkan hari kelahiran kepala keluarga adalah Jumat, maka pelaksanaannya Jumat Kliwon. Apabila hari kelahirannya Rabu, maka pelaksanaannya Rabu Kliwon, demikian seterusnya .

Neyag dilakukan pada sore hari, tempatnya di tengah-tengah areal yang akan dibangun rumah. Neyag dibiarkan semalaman dan pada keesokan paginya baru dilihat apakah terjadi perubahan ataukah tidak. Apabila di logak terlihat ada satu sampai tiga butir padi yang jatuh, terdapat semut, dan air tampak surut, maka itu menjadi pertanda yang kurang baik. Dengan demikian tidak dianjurkan untuk membangun rumah di areal tadi. 
Semua aturan yang terkait dengan membangun rumah, oleh warga dipatuhi demi keselamatan penghuni rumah. Pada intinya bahwa setiap warga yang membangun rumah mereka ingin agar rumah yang ditempati dapat mendatangkan rizki, "memberikan" kesehatan dan keselamatan bagi penghuninya.

\section{PENUTUP}

Kata "adat" tidak pernah bisa dilepaskan dari sebutan Kampung Adat Kuta. Label tersebut melekat bukan semata-mata sebagai asesoris. Kata "adat" yang melekat pada sebutan Kampung Adat Kuta menggambarkan bahwa dalam kesehariannya, warga Kuta tidak pernah lepas dari amanah leluhur. Mereka kental dalam balutan tradisi warisan generasi pendahulunya.

Salah satu amanah leluhur yang sangat dijaga adalah dalam hal membangun rumah tinggal. Dari paparan di muka, tampak bahwa ada tujuh hal yang harus dipatuhi oleh setiap warga yang akan membangun rumah. Ketujuh hal tersebut berkenaan dengan: material rumah, bentuk rumah, arah hadap rumah, letak rumah dikaitkan dengan rumah yang lain, letak ruang per ruang di dalam rumah, letak ruang per ruang dikaitkan dengan rumah yang lain, dan letak rumah dikaitkan dengan statusnya di dalam keluarga.

Ketujuh hal tersebut merupakan satu kesatuan yang tidak dapat dipisahkan antara satu dengan lainnya. Ketujuh hal tersebut menunjukkan bahwa warga Kuta memiliki konsep dalam menata rumah tinggal. Konsep tersebut mereka katakan sebagai amanah leluhur yang sesungguhnya mereka sendiri kurang atau bahkan tidak memahami maksudnya. Amanah tersebut mereka jaga dengan mewujudkannya dalam kehidupan mereka sehari-hari. Kepatuhan mereka secara tidak langsung merupakan upaya untuk menjauhkan dari musibah sebagai sangsi atas pelanggaran amanah.

Mereka (baca: warga Kuta) boleh tidak menangkap maksud dari amanah itu, namun demikian apabila dicerna secara seksama tentang ketujuh hal tersebut, tampak ada pesan yang ingin disampaikan para pendahulu mereka kepada generasi Kuta berikutnya. Ketujuh hal itu secara garis besar mengandung makna sebagai ajaran untuk menjaga keharmonisan dengan alam dan sesama manusia.

Ada nilai adaptasi dan nilai sosial yang dapat dipetik dari konsep tata ruang rumah di Kampung Kuta. Nilai-nilai tersebut adalah: nilai keselarasan dengan alam, nilai saling memerhatikan, nilai toleransi, nilai kepantasan, nilai keindahan, dan nilai sopan-santun. Nilainilai itu pula tampaknya yang mampu mempertahankan keberadaan Kampung Kuta sekaligus mewujudkan keharmonisan kehidupan berkeluarga dan antarwarganya. Selanjutnya tersimpulkan bahwa aturan adat berfungsi dalam menciptakan keselarasan, keserasian, dan keseimbangan hidup.

Nilai-nilai positif sebagai pedoman hidup sudah semestinya dapat dilestarikan dalam arti dilindungi, dikembangkan, dan dimanfaatkan. Terkait dengan nilai-nilai yang ditanamkan melalui konsep tata ruang rumah di Kampung Kuta, sudah seharusnya nilai-nilai itu bisa sampai pada generasi berikutnya. Dengan demikian alangkah baiknya apabila nilainilai yang belum atau tidak tertangkap maknanya itu, dicoba untuk diurai oleh para pemangku budaya setempat, dalam hal ini kuncen dan ketua adat kepada para warganya. Tidak lain agar amanah leluhur itu bukan sekadar sampai kepada anak cucu sebagai suatu aturan adat, akan tetapi juga bisa dipahami maksudnya.

Sudah terbukti selama puluhan hingga ratusan tahun bahwa konsep tata ruang rumah di Kampung Kuta apabila dilihat dari bentuk dan materialnya, 
mampu menyelamatkan warganya dari kondisi tanahnya yang labil dan gempa, menjaga dari kelembaban, dan mengatur keluar masuknya udara dari luar ke dalam rumah dan sebaliknya. Selain itu, apabila dilihat dari tata letak kamar, ruang per ruang, dan antarrumah, mampu menciptakan keharmonisan antar anggota keluarga dan antartetangga.

Terkait dengan nilai-nilai positif tersebut, ada baiknya konsep tata ruang rumah di Kampung Kuta tersebut dapat disosialisasikan kepada masyarakat luas dengan perhatian atau kefokusannya disesuaikan pada kondisi geografis masing-masing daerahnya.

Pada daerah-daerah dengan kondisi geografis serupa Kuta, hal yang perlu disosialisasikan selain terkait dengan tata ruang rumah dan letak rumah, terutama berkenaan dengan bentuk rumah dan material rumahnya. Sedangkan untuk daerah dengan kondisi geografis lainnya, setidaknya dapat disosialisasikan perihal tata ruang rumah dan letak rumahnya. Maksudnya adalah sebagai upaya menciptakan kehidupan masyarakat yang harmonis.

Selain itu, sebagai upaya mensosialisasikan keberadaan Kampung Adat Kuta, warga setempat dapat membuat cenderamata dalam bentuk miniatur Kampung Adat Kuta sebagai kenang-kenangan atau oleh-oleh para tamu yang berkunjung ke sana. Miniatur kampung adat ini juga dapat digunakan oleh pemerintah daerah setempat sebagai cenderamata para tamu.

\section{DAFTAR SUMBER}

Mustapa Abdullah dkk. 2000

Ensiklopedi Sunda. Pustaka Jaya.

Kartawinata, Ade M.

"Komunitas Adat dalam Lintasan Zaman: Eksistensi dan Bentuk Pemberdayaan",
Makalah dalam Kegiatan

Bimbingan Teknis Pemetaan

Komunitas Adat Direktorat

Kepercayaan terhadap Tuhan

Yang Maha Esa Direktorat

Jenderal Nilai Budaya, Seni dan Film Kementerian

Pariwisata dan Ekonomi

Kreatif, Bandung, 16 sd 18

November 2011.

Rif'ati, Heni Fajria dkk. 2002

Kampung Adat \& Rumah Adat

di Jawa Barat. Bandung:

Disbudpar Provinsi Jawa Barat.

SHM., Agraha Suhandi. 1981

Pola Hidup Masyarakat

Indonesia. Bandung: Jurusan

Antropologi Fakultas Sastra

UNPAD.

Sumardjo, Jakob. 2003

Simbol-Simbol Artefak Budaya

Sunda. Bandung: Kelir.

Anonim. 2010

Monografi Desa

Karangpaningal Kecamatan

Tambaksari Kabupaten Ciamis

Semester 2.

Hasil penelitian dalam 3 tahun terakhir:

- Upacara Tradisional pada

Masyarakat Baduy di

Kabupaten Lebak Provinsi

Banten.

- $\quad$ Pitung: Tokoh Legendaris

Masyarakat Betawi.

- $\quad$ Ondel-ondel, Kesenian

Tradisional Masyarakat

Betawi. 